\title{
Comparative Density Functional Theory Study on Thiacalix[4]arene Binding Modes for $\mathrm{Zn}^{2+}$ and $\mathrm{Cu}^{2+}$
}

\author{
A. Suwattanamala, A. L. Magalhães,* and J. A. N. F. Gomes \\ REQUIMTE/Departamento de Química, Faculdade de Ciências, Universidade do Porto, Rua do Campo Alegre, \\ 687, 4169-007 Porto, Portugal
}

Received: August 4, 2005; In Final Form: September 27, 2005

\begin{abstract}
A comparative study of the $\mathrm{Zn}^{2+}$ and $\mathrm{Cu}^{2+}$ complexation with thiacalix[4]arene is presented using density functional theory methods. The structures and energetics of the possible binding modes of both metal complexes are investigated in detail. Two types of patterns were found in the second deprotonated species, adjacent or opposite phenolate groups, which determine the stability of the different binding modes. The most stable structure for both metal ions was predicted to be a distorted square planar coordination at lower rim with opposite phenolate groups, which has never been referred to in the literature. The results show a higher complexation ability of $\mathrm{Cu}^{2+}$ than $\mathrm{Zn}^{2+}$ for all of the binding modes, which is in good agreement with the previous study on liquid-liquid extraction experiments. The analysis of the electrostatic potential surfaces of the metal complexes allows us to conclude that the different complexation features can also be explained by a bigger charge transfer from the metal to the coordinated atoms in the case of the $\mathrm{Cu}^{2+}$ complex.
\end{abstract}

\section{Introduction}

In the past decade, thiacalixarene ${ }^{1}$ was proposed as a novel member of the well-known calixarene family, and it has attracted considerable interest in the fast-growing field of supramolecular chemistry. ${ }^{2}$ The presence of four sulfur atoms instead of the bridge methylene groups imposes many novel features such as excellent coordination abilities toward transition metal ions, chemical modification (oxidation) of bridges, different cavity sizes, and conformational preferences that have never been reported in the previous "classical" calixarenes. ${ }^{3}$ Thiacalixarenes have already been explored as building blocks and/or molecular platforms for interesting potential applications such as inclusion of a variety of guest molecules, recognition of metal ions, chiral recognition, novel anion receptors, and novel dendritic-shelled molecular receptors. ${ }^{2,4}$

Very recently, theoretical calculations using density functional theory (DFT) methodology have been successfully applied in the study of the structure and conformational equilibrium of thiacalix[4]arene and its tetraamino and tetramercapto derivatives. 5 Moreover, the complexes of each conformer of tetraaminothiacalix[4] arene with $\mathrm{Zn}^{2+}$ were recently investigated by high DFT levels. ${ }^{7}$ Complexation features of $p$-tert-butylthiacalix[4]arene toward transition metal ions were intensively explored by solvent extraction method, 8,9 and spectroscopic measurement indicated that the $\mathrm{Zn}^{2+}$ complexation is revealed by the second deprotonated ligand. ${ }^{9 a}$ This result suggested that two adjacent phenolate and one sulfur took part in the metalion coordination in order to form a set of two five-membered rings, and this proposal was also assumed for complexes of the other transition metals in solution. ${ }^{9,10}$ A theoretical study of the $\mathrm{Zn}^{2+}$ complex ${ }^{11}$ also showed good agreement with the solidstate data. ${ }^{12}$ Though some other possible binding modes might be proposed based on that assumption, no other structures have been referred to in the literature. On the other hand, the four

* To whom correspondence should be addressed. Tel: +(351)-226082804. Fax: +(351)-226-082959. E-mail: almagalh@fc.up.pt. bulky tert-butyl groups at upper rim do not play an important role in the metal binding, therefore the thiacalix[4]arene may be used as a good simple model to understand the characteristics of complexation.

In this work, the structural details of each conformer of thiacalix[4]arene were investigated, and a comparative study on their complexation ability toward the transition metal ions $\mathrm{Zn}^{2+}$ and $\mathrm{Cu}^{2+}$ was performed at B3LYP and PBE1PBE ${ }^{13,14}$ hybrid density functional theory (HDFT) methods. Structural and energetic information for each possible binding mode in the coordination of both ions is reported. To discuss the ability of thiacalix[4]arene to selectively bind transition metal ions, which is one fundamental aspect of host-guest chemistry, data on the representation of the electrostatic potential over electronic isodensity surfaces of some related systems are also reported. The main goal of this work is to open new aspects of the stronger ability of thiacalixarene to bind transition metals when compared with "classical" calixarenes. In addition, the understanding of the complexation features of this compound will help future design of novel molecular receptors or molecular devices based on thiacalix[4]arene scaffold for many applications in supramolecular chemistry.

\section{Computational Details}

The structures of the four main conformers of thiacalix[4]arene, namely, cone, partial cone (paco), 1,2-alternate (1,2alt), and 1,3-alternate (1,3-alt), were obtained by complete optimization without any geometrical constraints using HDFT methods based on the generalized gradient approximation (GGA) functional theory and including Hartree-Fock (HF) theory. Among these hybrid functionals, the most popular, B3LYP, ${ }^{15}$ Becke's three-parameter hybrid exchange functional combined with the correlation functional of Lee, Yang, and Parr, and the more recent PBE1PBE (or sometimes called PBE0), ${ }^{13,14}$ Perdew, Burke, and Ernzerhof's one-parameter hybrid exchange functional combined with their correlation functional, were chosen to perform calculations with the $6-31 \mathrm{G}(\mathrm{d})$ basis set. The 
molecular structure of the first and second deprotonated forms of cone conformer were also investigated at the same HDFT.

$\mathrm{Zn}$ and $\mathrm{Cu}$ were selected to carry out a comparative study on the complexation ability of the second deprotonated species of thiacalix[4]arene toward transition metals. Several different structures based on the possible binding modes of the metal ion at lower rim of the thiacalix[4]arene were considered as starting points for complete geometry optimizations. The 6-31G(d) basis set was used on "all electrons" of $\mathrm{C}, \mathrm{H}, \mathrm{O}$, and $\mathrm{S}$ atoms, and the relativistic effective core potentials (ECP) CEP-31G basis set (CEP is sometime referred to SBKJC potential, which stands for Stevens-Basch-Krauss-Jasien-Cundari) ${ }^{16}$ were used for $\mathrm{Zn}$ and $\mathrm{Cu}$. All the "inner electrons" of the $\mathrm{Zn}$ and $\mathrm{Cu}$ atoms were replaced and described with a "core" potential while the other electrons ( $3 \mathrm{~s}, 3 \mathrm{p}, 3 \mathrm{~d}, 4 \mathrm{~s}$ orbitals) were described with a split valence basis set without an additional set of polarization functions. The binding energy was obtained as the difference between the total energy of the metal complex and the sum of the total energies of the most stable structures of the isolated moieties. The basis set superposition error (BSSE) for all the $\mathrm{Zn}^{2+}$ complexes was estimated with the new counterpoise method which automates the geometry optimization of the complexes on the potential surfaces that are corrected for this error. ${ }^{17}$ To understand the role that electrostatic interactions play in the complexation of both metal ions with thiacalix[4]arene, electrostatic potential surfaces of the most stable complexes were calculated at the same B3LYP level. All the calculations have been carried out with the GAUSSIAN 03 program. ${ }^{18}$ Graphics of all the optimized structures were produced with the MOLDEN package, ${ }^{19}$ whereas the electrostatic potential surfaces were constructed with the MOLEKEL 4.3 package. ${ }^{20}$

\section{Results and Discussion}

3.1. Structures and Hydrogen Bonds of Thiacalix[4]arenes. The structures of the four main conformers cone, paco, 1,2-alt, and 1,3-alt of thiacalix[4]arene are presented in Figure 1. Both HDFT functionals point to the cone as the most stable conformer where a cyclic array of four hydrogen bonds in the lower rim seems to be the reason for the energy stabilization of this conformer. Taking the total energy of the most stable structure as a reference, the energy difference $(\Delta E)$ of the other conformers are reported in Table 1. All the calculations point toward the following stability ordering of the thiacalix[4]arene: 1,2-alt $<1,3$-alt $<$ paco $<$ cone, which is in good agreement with an early theoretical study done at B3LYP/6-31G(d,p) level. ${ }^{5}$ The energy gap between 1,2-alt and 1,3-alt is reduced at B3LYP/6-31G(d) when compared with the previous study at the B3LYP/6-31G(d,p) level. ${ }^{5}$ The $\Delta E$ values for all the conformers obtained at PBE1PBE are smaller than those calculated with the B3LYP functional by ca. $0.7-0.9 \mathrm{kcal} \mathrm{mol}^{-1}$ using the same 6-31G(d) basis set. As shown in Figure 1, the number of hydrogen bonds $\mathrm{O}-\mathrm{H} \cdots \mathrm{O}$ at the lower rim is found to be four in the cone conformer, two in paco and 1,2-alt, and none in the 1,3-alt, which is the same as found in calix[4]arene. ${ }^{21}$ The very small energy difference between 1,3-alt and 1,2-alt may suggest that a sort of $\mathrm{O}-\mathrm{H} \cdots \mathrm{S}$ intramolecular hydrogen bond may play a dominant role in the stabilization of 1,3-alt, and that they can even overcome the importance of the $\mathrm{O}-\mathrm{H} \cdots \mathrm{O}$ hydrogen bonds in 1,2-alt.

The optimized structures for cone conformer of thiacalix[4]arene in neutral $\left(\mathrm{LH}_{4}\right)$, first $\left(\mathrm{LH}_{3}{ }^{-}\right)$, and second $\left(\mathrm{LH}_{2}{ }^{2-}\right)$ deprotonated species are shown in Figure 2. Two different possible structures for the second deprotonated species were found, which have never been mentioned in previous studies.
The structure with pattern I presents two adjacent deprotonated phenol groups, and it is less stable by $1.23 \mathrm{kcal} \mathrm{mol}^{-1}$ than the structure with pattern II, which shows two opposite deprotonated phenol groups. This can be rationalized by the weaker repulsion felt by the negative phenolate groups in opposite positions as compared with adjacent positions.

Some selected geometric parameters of the neutral and deprotonated species of cone conformer obtained at different HDFT levels are reported in Table 2 (a more complete set of parameters can be found in Supporting Information). All calculations show that the neutral species possesses $C_{4}$ symmetry, in agreement with an earlier theoretical study. ${ }^{5}$ This is confirmed by the identical values of either the $\mathrm{O}_{1}-\mathrm{O}_{3}$ and $\mathrm{O}_{2}-$ $\mathrm{O}_{4}$ distances or the two angles $\phi$ between opposite phenol units (see Table 2). By contrast, published X-ray structural data indicates that the neutral form presents $C_{2}$ symmetry. ${ }^{22}$ However, a recent Fourier transform infrared spectroscopic study suggests that thiacalix[4]arene may adopt the cone conformer with $C_{4}$ symmetry in $\mathrm{CCl}_{4}$ solution. ${ }^{23}$ The majority of the structural parameters obtained at the B3LYP/6-31G(d) level seems to remain unchanged except the $\mathrm{C}-\mathrm{C}-\mathrm{O}$ bond angles, which decreased by about $4.0^{\circ}$ when compared with the previous study at the B3LYP/6-31G(d,p) level. ${ }^{5}$ On the other hand, PBE1PBE yielded almost the same results as B3LYP with the same 6-31G(d) basis set. Although the comparison between the gasand condensed-phase structures cannot be done directly, there is a good agreement between the theoretical predictions and the experimental X-ray crystal results for the thiacalix[4]arene. The majority of the geometric parameters seems to remain unchanged upon the deprotonation process except for the $\mathrm{C}-\mathrm{O}$ and $\mathrm{O}-\mathrm{O}$ bond distances and the $\mathrm{C}-\mathrm{C}-\mathrm{O}$ bond angles at both HDFT levels. The $\mathrm{C}-\mathrm{O}$ bond distance of the phenolate is shortened by ca. 0.06 and $0.09 \AA$ for $\mathrm{LH}_{3}{ }^{-}$and $\mathrm{LH}_{2}{ }^{2-}$ species, respectively, whereas the $\mathrm{C}-\mathrm{C}-\mathrm{O}$ bond angles is increased by about $3.5^{\circ}$ for $\mathrm{LH}_{3}{ }^{-}$and $5.0^{\circ}$ for $\mathrm{LH}_{2}{ }^{2-}$ when compared with $\mathrm{LH}_{4}$. The PBE1PBE functional seems to yield almost the same results as B3LYP, which shows that this modern hybrid functional can be a good alternative to study this molecular system.

As expected, the optimized structures exhibit arrays of hydrogen bonds that contribute to stabilize these species (see Figure 2). Upon first and second deprotonation of the neutral form, the number of hydrogen bonds between hydroxyl groups are reduced from four to three and two, respectively. The hydrogen bonding parameters for each species are reported in Table 3. The hydrogen bond angles of the deprotonated species increase, and the hydrogen bond distances seem to be shorter than in the neutral species. However, both HFDT provide similar results on these parameters.

3.2. Structure and Energetic Analysis of the Metal Complexes. Although no supporting experimental data on thiacalix[4]arene complexes have been achieved yet, the complexation ability of a similar compound possessing tert-butyl groups at para positions, named $p$-tert-butylthiacalix[4]arene, was previously investigated..$^{9,24}$ Fortunately, the bulky tert-butyl groups do not seem to interfere in the stabilization of the metal complex, therefore thiacalix[4]arene can be used as a smaller model in the complexation study with transition metals. Previous solvent extraction ${ }^{9 a, 24}$ and $\mathrm{NMR}^{9 \mathrm{a}}$ studies suggested that the stoichiometry of the metal complexes of $p$-tert-butylthiacalix[4] arene was as a 1:1 neutral complex $\left[\mathrm{M}^{2+} \mathrm{H}_{2} \mathrm{~L}^{2-}\right]$, where $\mathrm{M}^{2+}$ and $\mathrm{H}_{2} \mathrm{~L}^{2-}$ denote the metal ion and the second deprotonated ligand, respectively. Two patterns of second deprotonated structures of thiacalix[4]arene, either with adjacent or opposite phenol groups, were presented in the previous section; therefore 


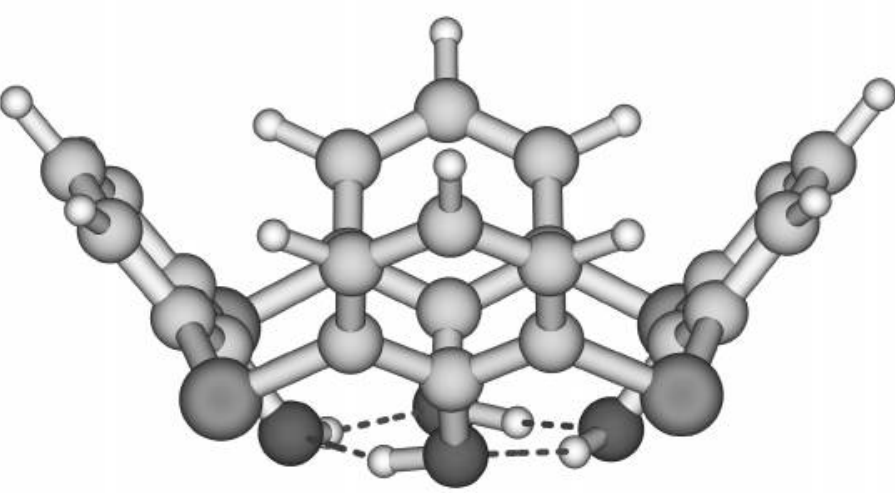

cone

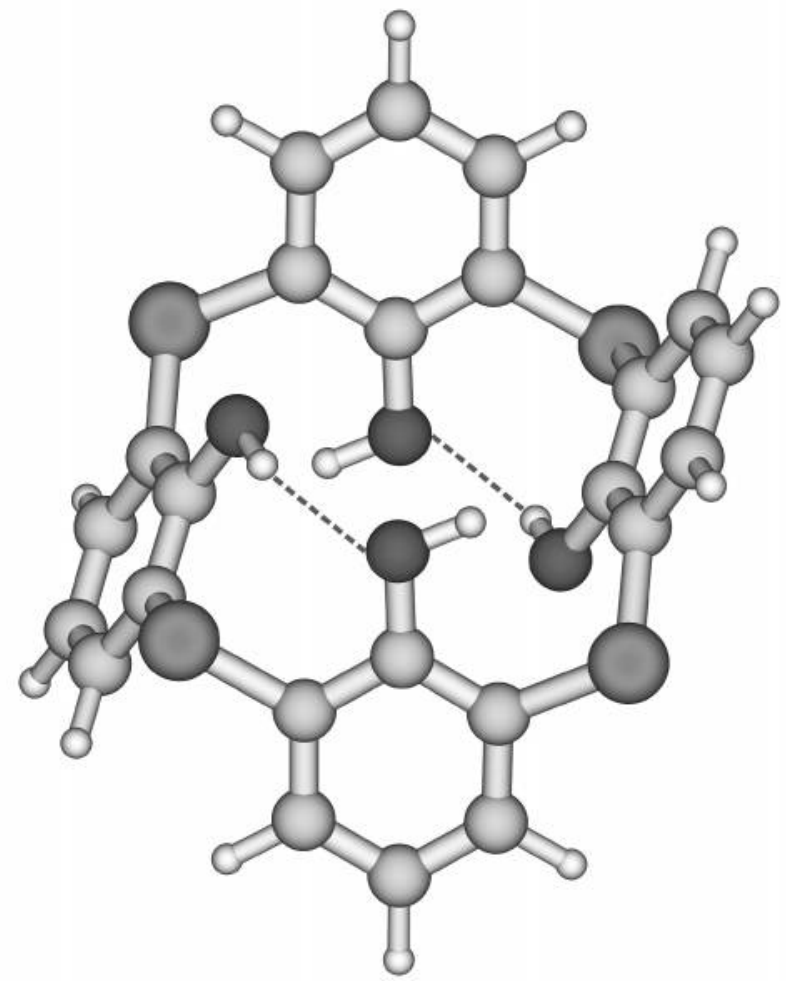

1,2-alternate
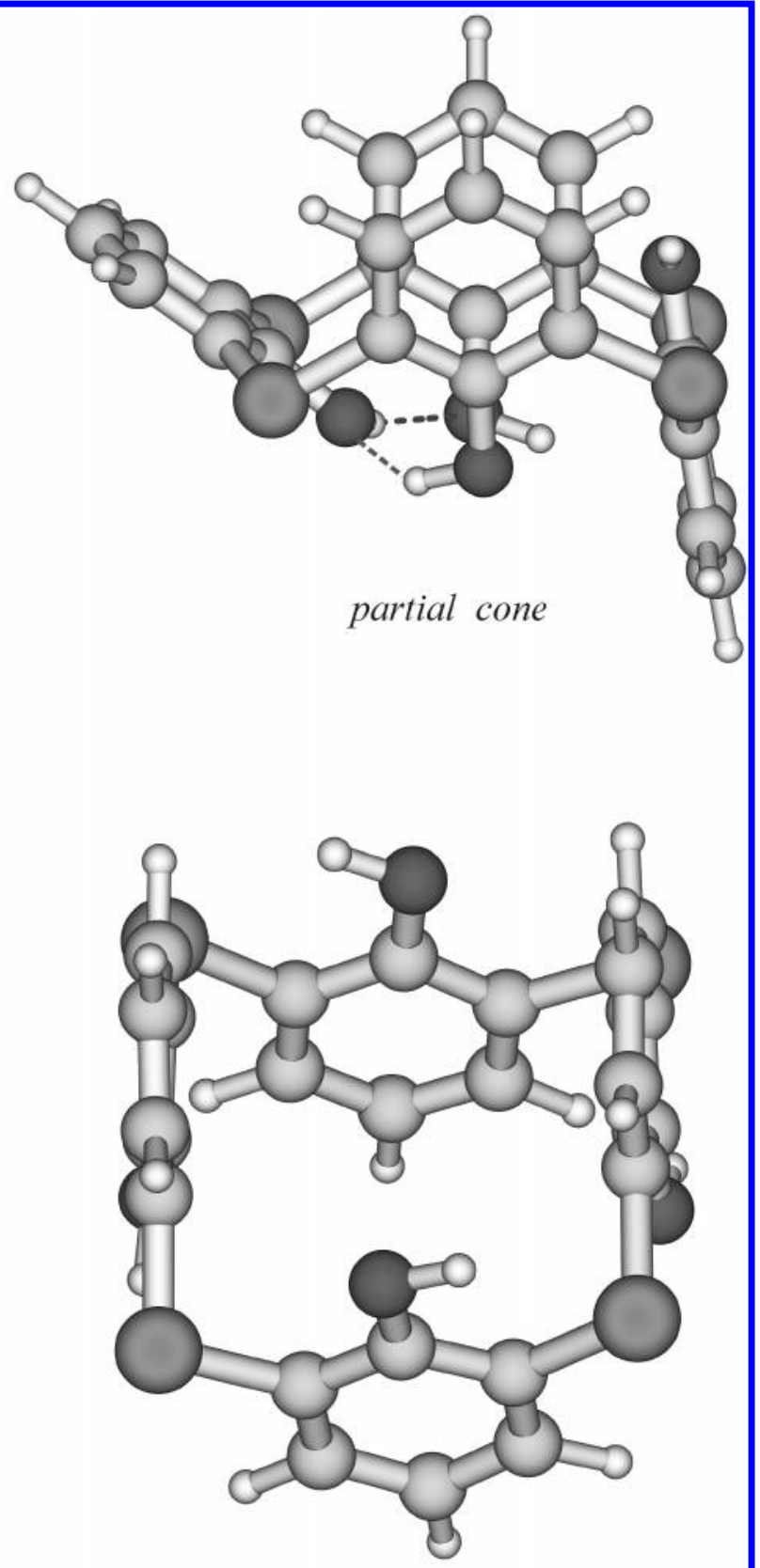

1,3-alternate

Figure 1. Optimized structures of the four main conformers of thiacalix[4]arene obtained at B3LYP/6-31G(d) level.

TABLE 1: Total Energies (in Hartrees) for the cone Conformer of Thiacalix[4] arene and Relative Energy $(\Delta E$, $\mathrm{kcalmol}^{-1}$ ) of the Other Conformers at Different HDFT Levels

\begin{tabular}{lccccc}
\hline & total energy & & \multicolumn{3}{c}{$\Delta E$} \\
\cline { 2 - 3 } \cline { 5 - 6 } method & \multicolumn{1}{c}{ cone } & & $\begin{array}{c}\text { partial } \\
\text { cone }\end{array}$ & $\begin{array}{c}1,2- \\
\text { alternate }\end{array}$ & $\begin{array}{c}1,3- \\
\text { alternate }\end{array}$ \\
\hline $\mathrm{B} 3 \mathrm{LYP} / 6-31 \mathrm{G}(\mathrm{d})^{a}$ & -2817.84142 & & 10.7 & 14.8 & 14.7 \\
$\mathrm{PBE} 1 \mathrm{PBE} / 6-31 \mathrm{G}(\mathrm{d})^{a}$ & -2815.86846 & & 9.8 & 14.1 & 13.6 \\
$\mathrm{~B} 3 \mathrm{LYP} / 6-31 \mathrm{G}(\mathrm{d}, \mathrm{p})^{b}$ & -2817.88206 & & 10.1 & 16.5 & 13.8
\end{tabular}

${ }^{a}$ Geometries optimized at this level of theory. ${ }^{b}$ From ref 5.

the structural and energetic analysis of the binding modes will consider both patterns. Our interest is restricted to the binding modes in which phenolate and phenol oxygens and sulfur bridging atoms at lower rim coordinate to the metal ion in several different ways. The various metal ion binding modes are classified by the number and type of binding atoms. For example, $\mathrm{O}^{-}+\mathrm{O}+\mathrm{S}$ (adj) denotes the second deprotonated species possessing adjacent pattern and the metal coordinated to one phenolate oxygen, one phenol oxygen, and one sulfur atom. In concern with the local minima with relevant binding energies, four possible different binding modes were obtained with adjacent phenolate groups, whereas only two different binding modes were achieved with opposite pattern. These are denoted as $2 \mathrm{O}^{-}+\mathrm{S}(\operatorname{adj}), \mathbf{1} ; \mathrm{O}^{-}+\mathrm{O}+\mathrm{S}(\operatorname{adj}), 2 ; \mathrm{O}^{-}+\mathrm{O}+$ $\mathrm{S}$ (opp), 3; $2 \mathrm{O}+\mathrm{S}$ (adj), 4; $2 \mathrm{O}^{-}+2 \mathrm{O}(\operatorname{adj}), \mathbf{5} ; 2 \mathrm{O}^{-}+2 \mathrm{O}$ (opp), 6 (see Table 4). In practice, all the calculations predicted only two and five distinct binding modes for $\mathrm{Zn}^{2+}$ (see Figure 3 ) and for $\mathrm{Cu}^{2+}$ (see Figure 4), respectively.

Two different arrays of hydrogen bonds labeled $\mathbf{A}$ and $\mathbf{B}$ were found in $\mathbf{1}$ of both metal complexes (see Figures 3 and 4). The 


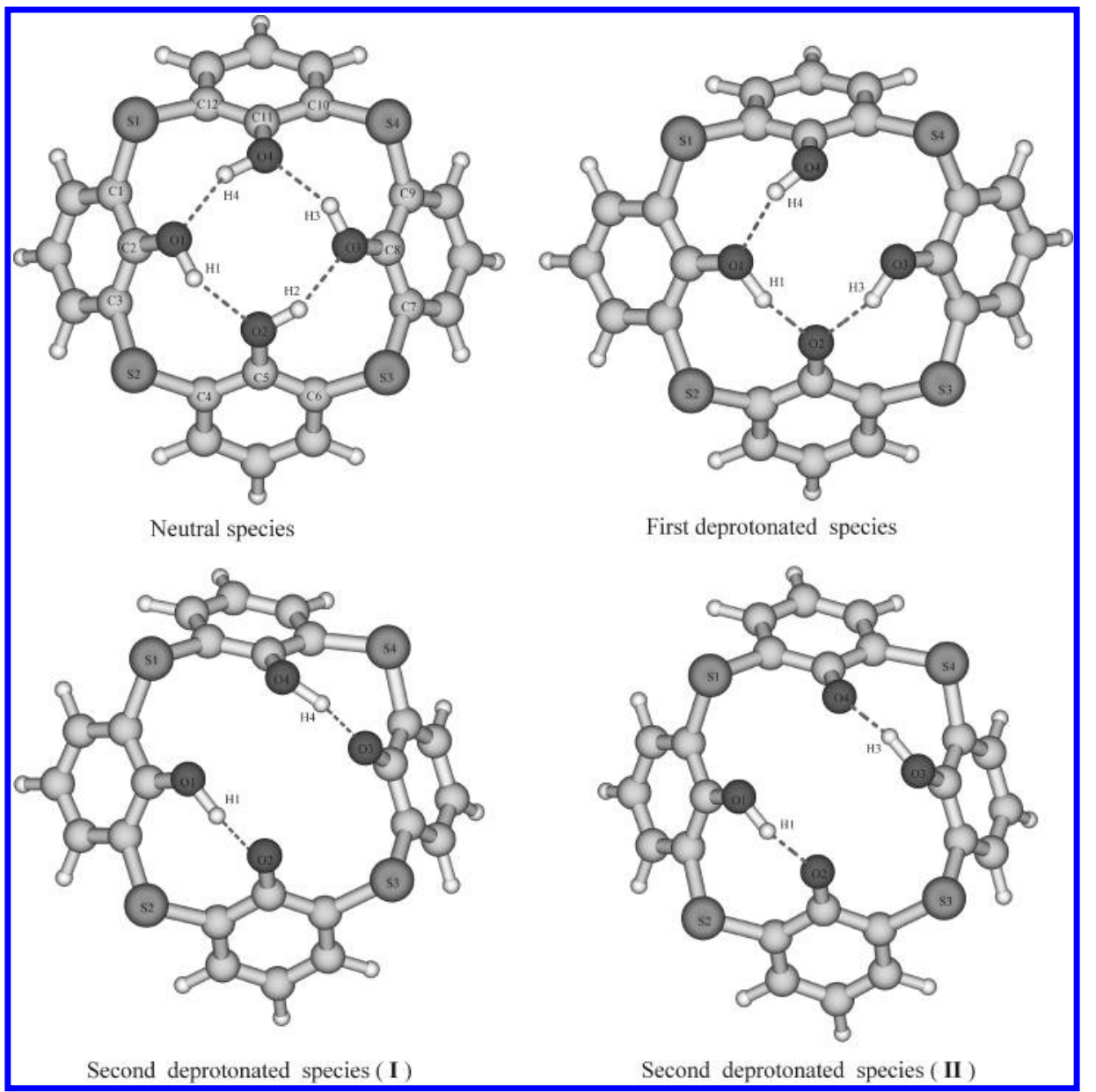

Figure 2. Optimized structures of neutral and deprotonated species of cone conformer of thiacalix[4]arene obtained at B3LYP/6-31G(d) level.

TABLE 2: Values of Some Relevant Structural Parameters for Each Species of the cone Conformer of the Thiacalix[4]arene at Different HDFT Methods (Atom Numbering Corresponds to Figure 2)

\begin{tabular}{|c|c|c|c|c|c|c|c|c|c|c|}
\hline & \multicolumn{4}{|c|}{ B3LYP/6-31G(d) } & \multirow{2}{*}{$\frac{\mathrm{B} 3 \mathrm{LYP} / 6-31 \mathrm{G}(\mathrm{d}, \mathrm{p})^{a}}{\mathrm{LH}_{4}}$} & \multicolumn{4}{|c|}{ PBE1PBE/6-31G(d) } & \multirow{2}{*}{$\begin{array}{c}\mathrm{X}-\text { ray }^{b} \\
\mathrm{LH}_{4} \\
\end{array}$} \\
\hline & $\mathrm{LH}_{4}$ & $\mathrm{LH}_{3}^{-}$ & $\mathrm{LH}_{2}{ }^{2-}(\mathbf{I})$ & $\mathrm{LH}_{2}{ }^{2-}(\mathbf{I I})$ & & $\mathrm{LH}_{4}$ & $\mathrm{LH}_{3}^{-}$ & $\mathrm{LH}_{2}{ }^{2-}(\mathbf{I})$ & $\mathrm{LH}_{2}{ }^{2-}(\mathbf{I I})$ & \\
\hline & & & & & Bond Distance $(\AA)$ & & & & & \\
\hline $\mathrm{S}_{1}-\mathrm{C}_{1}$ & 1.80 & 1.80 & 1.81 & 1.81 & 1.80 & 1.79 & 1.78 & 1.79 & 1.79 & 1.76 \\
\hline $\mathrm{C}_{1}-\mathrm{C}_{2}$ & 1.41 & 1.42 & 1.43 & 1.43 & 1.41 & 1.41 & 1.41 & 1.43 & 1.42 & 1.41 \\
\hline $\mathrm{C}_{2}-\mathrm{O}_{1}$ & 1.36 & 1.34 & 1.31 & 1.32 & 1.36 & 1.35 & 1.33 & 1.30 & 1.31 & 1.36 \\
\hline $\mathrm{C}_{5}-\mathrm{O}_{2}$ & 1.36 & 1.30 & 1.28 & 1.27 & 1.36 & 1.35 & 1.29 & 1.27 & 1.26 & 1.36 \\
\hline $\mathrm{C}_{8}-\mathrm{O}_{3}$ & 1.36 & 1.33 & 1.27 & 1.32 & 1.36 & 1.35 & 1.32 & 1.27 & 1.31 & 1.38 \\
\hline $\mathrm{C}_{11}-\mathrm{O}_{4}$ & 1.36 & 1.34 & 1.31 & 1.27 & 1.36 & 1.35 & 1.33 & 1.30 & 1.26 & 1.36 \\
\hline $\mathrm{O}_{1}-\mathrm{O}_{3}$ & 3.89 & 3.61 & 4.15 & 4.22 & 3.87 & 3.87 & 3.56 & 4.14 & 4.20 & 4.21 \\
\hline $\mathrm{O}_{2}-\mathrm{O}_{4}$ & 3.88 & 4.07 & 4.18 & 4.14 & 3.87 & 3.86 & 4.07 & 4.14 & 4.13 & 3.60 \\
\hline & & & & & Bond Angle $\left({ }^{\circ}\right)$ & & & & & \\
\hline $\mathrm{C}_{12}-\mathrm{S}_{1}-\mathrm{C}_{1}$ & 104.2 & 104.4 & 103.3 & 103.5 & 104.3 & 103.8 & 103.8 & 102.9 & 103.0 & 101.9 \\
\hline $\mathrm{S}_{1}-\mathrm{C}_{1}-\mathrm{C}_{2}$ & 120.7 & 121.1 & 120.8 & 121.3 & 120.7 & 120.4 & 120.6 & 120.5 & 121.0 & 120.3 \\
\hline $\mathrm{C}_{1}-\mathrm{C}_{2}-\mathrm{O}_{1}$ & 118.1 & 118.5 & 119.1 & 119.3 & 122.2 & 118.2 & 118.4 & 119.4 & 119.4 & 119.4 \\
\hline $\mathrm{C}_{2}-\mathrm{C}_{3}-\mathrm{S}_{2}$ & 120.8 & 122.0 & 121.5 & 121.4 & 120.7 & 120.4 & 121.7 & 121.1 & 121.1 & 120.3 \\
\hline $\mathrm{C}_{4}-\mathrm{C}_{5}-\mathrm{O}_{2}$ & 118.1 & 121.7 & 122.5 & 123.0 & 122.2 & 118.2 & 121.7 & 122.6 & 123.1 & 120.3 \\
\hline $\mathrm{C}_{7}-\mathrm{C}_{8}-\mathrm{O}_{3}$ & 118.1 & 123.4 & 122.5 & 119.3 & 122.2 & 118.2 & 123.6 & 122.5 & 119.4 & 119.6 \\
\hline $\mathrm{C}_{10}-\mathrm{C}_{11}-\mathrm{O}_{4}$ & 118.1 & 119.5 & 123.5 & 123.0 & 122.2 & 118.2 & 119.7 & 123.6 & 123.1 & 120.4 \\
\hline$\phi\left(\left(^{\circ}\right)\right.$ & $77.8 ; 78.4$ & $97.5 ; 66.5$ & $68.3 ; 81.8$ & $77.2 ; 74.9$ & $77.2 ; 77.4$ & $76.6 ; 76.6$ & $99.0 ; 63.1$ & $67.0 ; 80.6$ & $75.3 ; 74.6$ & $91.7 ; 54.5$ \\
\hline
\end{tabular}

${ }^{a}$ From ref $5 .{ }^{b}$ From ref 22.

corresponding structures of the former type are predicted to be more stable than those of the latter one by ca. $0.5 \mathrm{kcal} \mathrm{mol}^{-1}$ at the B3LYP level, but that energy gap is reduced $0.3 \mathrm{kcal} \mathrm{mol}^{-1}$ at PBE1PBE. In the case of $\mathbf{2}$ of the $\mathrm{Cu}^{2+}$ complex, only one arrangement of hydrogen bonds is possible. On the other hand, two different ways may be proposed in $\mathbf{3}$, namely, the one shown in Figure 4 and an alternative structure where the two hydrogens interact with the same oxygen. However, through the DFT calculations it was concluded that the latter does not correspond to a local minimum in the potential-energy hypersurface. Two possibilities appear also for both $\mathbf{5}$ and $\mathbf{6}$ of the $\mathrm{Cu}^{2+}$ complexes, but in the case of the $\mathrm{Zn}^{2+}$ complexes, it was found only in $\mathbf{6}$. It is worthwhile to note that the corresponding structure of $\mathbf{6 A}$ has a lower energy than 6B for both metal complexes. By contrast, the corresponding structure of $\mathbf{5 B}$ is more stable than $\mathbf{5 A}$ in the $\mathrm{Cu}^{2+}$ complex. $\mathbf{4}$, where the metal is coordinated to 
TABLE 3: HDFT-Optimized Hydrogen Bonding Parameters for All the Neutral and Deprotonated Forms of cone Conformer of Thiacalix[4] arene (Atom Numbering Corresponds to Figure 2)

\begin{tabular}{|c|c|c|c|c|c|c|c|c|c|}
\hline & \multicolumn{4}{|c|}{ B3LYP/6-31G(d) } & \multirow{2}{*}{$\frac{\mathrm{B} 3 \mathrm{LYP} / 6-31 \mathrm{G}(\mathrm{d}, \mathrm{p})^{a}}{\mathrm{LH}_{4}}$} & \multicolumn{4}{|c|}{ PBE1PBE/6-31G(d) } \\
\hline & $\mathrm{LH}_{4}$ & $\mathrm{LH}_{3}^{-}$ & $\mathrm{LH}_{2}{ }^{2-}(\mathbf{I})$ & $\mathrm{LH}_{2}^{2-}($ II $)$ & & $\mathrm{LH}_{4}$ & $\mathrm{LH}_{3}^{-}$ & $\mathrm{LH}_{2}^{2-}(\mathbf{I})$ & $\overline{\mathrm{LH}_{2}{ }^{2-}(\text { II })}$ \\
\hline \multicolumn{10}{|c|}{ Bond Distance $(\AA)$} \\
\hline $\mathrm{O}_{1}-\mathrm{H}_{1}$ & 0.99 & 1.04 & 1.07 & 1.04 & & 0.99 & 1.04 & 1.07 & 1.04 \\
\hline $\mathrm{H}_{1}-\mathrm{O}_{2}$ & 1.83 & 1.53 & 1.42 & 1.50 & 1.82 & 1.83 & 1.50 & 1.39 & 1.47 \\
\hline $\mathrm{O}_{2}-\mathrm{H}_{2}$ & 0.99 & & & & & 0.99 & & & \\
\hline $\mathrm{H}_{2}-\mathrm{O}_{3}$ & 1.83 & & & & 1.82 & 1.83 & & & \\
\hline $\mathrm{O}_{3}-\mathrm{H}_{3}$ & 0.99 & 1.01 & & 1.04 & & 0.99 & 1.01 & & 1.04 \\
\hline $\mathrm{H}_{3}-\mathrm{O}_{4}$ & 1.83 & & & 1.50 & 1.82 & 1.83 & & & 1.47 \\
\hline $\mathrm{H}_{3}-\mathrm{O}_{2}$ & & 1.59 & & & & & 1.57 & & \\
\hline $\mathrm{O}_{4}-\mathrm{H}_{4}$ & 0.99 & 0.98 & 1.06 & & & 0.99 & 0.98 & 1.07 & \\
\hline $\mathrm{H}_{4}-\mathrm{O}_{1}$ & 1.83 & 1.92 & & & 1.82 & 1.83 & 1.93 & & \\
\hline $\mathrm{H}_{4}-\mathrm{O}_{3}$ & & & 1.43 & & & & & 1.39 & \\
\hline \multicolumn{10}{|c|}{ Bond Angle $\left({ }^{\circ}\right)$} \\
\hline $\mathrm{O}_{1}-\mathrm{H}_{1}-\mathrm{O}_{2}$ & 152.2 & 165.8 & 168.3 & 168.0 & & 151.3 & 165.4 & 168.1 & 167.6 \\
\hline $\mathrm{O}_{2}-\mathrm{H}_{2}-\mathrm{O}_{3}$ & 152.2 & & & & & 151.3 & & & \\
\hline $\mathrm{O}_{3}-\mathrm{H}_{3}-\mathrm{O}_{4}$ & 152.1 & & & 168.0 & & 151.3 & & & 167.6 \\
\hline $\mathrm{O}_{3}-\mathrm{H}_{3}-\mathrm{O}_{2}$ & & 160.8 & & & & & 160.3 & & \\
\hline $\mathrm{O}_{4}-\mathrm{H}_{4}-\mathrm{O}_{1}$ & 152.1 & 150.0 & & & & 151.3 & 147.6 & & \\
\hline $\mathrm{O}_{4}-\mathrm{H}_{4}-\mathrm{O}_{3}$ & & & 168.4 & & & & & 168.0 & \\
\hline
\end{tabular}

${ }^{a}$ From ref 5.

TABLE 4: Energetic Analysis for Thiacalix[4]arene Complexes with $\mathrm{Zn}^{2+}$ and $\mathrm{Cu}^{2+a}$

\begin{tabular}{|c|c|c|c|c|c|}
\hline \multirow[b]{2}{*}{ binding mode ${ }^{b}$} & \multirow[b]{2}{*}{ method } & \multicolumn{2}{|c|}{$\mathrm{Zn}^{2+}$} & \multicolumn{2}{|c|}{$\mathrm{Cu}^{2+}$} \\
\hline & & $\Delta E_{\text {bind }}$ & $\Delta E_{\text {rel }}$ & $\Delta E_{\text {bind }}$ & $\Delta E_{\text {rel }}$ \\
\hline \multirow[t]{2}{*}{$2 \mathrm{O}^{-}+\mathrm{S}(\operatorname{adj}): \mathbf{1 A}$} & B3LYP/6-31G(d) & $-622.22(-613.71)^{c}$ & $1.76(2.58)^{c}$ & -654.25 & 1.94 \\
\hline & PBE1PBE/6-31G(d) & $-622.40(-615.14)$ & $1.81(2.28)$ & -652.65 & 1.10 \\
\hline \multirow[t]{2}{*}{$2 \mathrm{O}^{-}+\mathrm{S}(\operatorname{adj}): \mathbf{1 B}$} & B3LYP/6-31G(d) & $-621.90(-613.59)$ & $2.08(2.69)$ & -653.75 & 2.44 \\
\hline & PBE1PBE/6-31G(d) & $-622.38(-615.23)$ & $1.83(2.19)$ & -652.47 & 1.28 \\
\hline \multirow[t]{2}{*}{$\mathrm{O}^{-}+\mathrm{O}+\mathrm{S}(\operatorname{adj}): 2$} & B3LYP/6-31G(d) & & & -639.50 & 16.69 \\
\hline & PBE1PBE/6-31G(d) & & & -634.72 & 19.03 \\
\hline \multirow[t]{2}{*}{$\mathrm{O}^{-}+\mathrm{O}+\mathrm{S}(\mathrm{opp}): \mathbf{3}$} & B3LYP/6-31G(d) & & & -640.07 & 16.11 \\
\hline & PBE1PBE/6-31G(d) & & & -636.37 & 17.37 \\
\hline \multirow[t]{2}{*}{$2 \mathrm{O}+\mathrm{S}(\operatorname{adj}): 4$} & B3LYP/6-31G(d) & & & & \\
\hline & PBE1PBE/6-31G(d) & & & & \\
\hline \multirow[t]{2}{*}{$2 \mathrm{O}^{-}+2 \mathrm{O}(\operatorname{adj}): \mathbf{5 A}$} & B3LYP/6-31G(d) & & & -648.44 & 7.75 \\
\hline & PBE1PBE/6-31G(d) & & & -644.88 & 8.87 \\
\hline \multirow[t]{2}{*}{$2 \mathrm{O}^{-}+2 \mathrm{O}(\operatorname{adj}): \mathbf{5 B}$} & B3LYP/6-31G(d) & & & -653.91 & 2.28 \\
\hline & PBE1PBE/6-31G(d) & & & -651.07 & 2.67 \\
\hline \multirow[t]{2}{*}{$2 \mathrm{O}^{-}+2 \mathrm{O}$ (оpp): $\mathbf{6 A}$} & B3LYP/6-31G(d) & $-623.98(-616.29)$ & $0.00(0.00)$ & -656.19 & 0.00 \\
\hline & PBE1PBE/6-31G(d) & $-624.21(-617.42)$ & $0.00(0.00)$ & -653.75 & 0.00 \\
\hline \multirow[t]{2}{*}{$2 \mathrm{O}^{-}+2 \mathrm{O}$ (орp): $6 \mathbf{B}$} & B3LYP/6-31G(d) & $-621.52(-613.58)$ & $2.46(2.71)$ & -654.35 & 1.84 \\
\hline & PBE1PBE/6-31G(d) & $-621.36(-614.32)$ & $2.85(3.10)$ & -651.71 & 2.04 \\
\hline
\end{tabular}

${ }^{a}$ Binding energies, $\Delta E_{\text {bind, }}$, and relative binding energies, $\Delta E_{\text {rel }}$, are given in $\mathrm{kcal} \mathrm{mol}^{-1}$. ${ }^{b}$ All binding modes of $\mathrm{Zn}^{2+}$ and $\mathrm{Cu}^{2+}$ were optimized at B3LYP and PBE1PBE using the 6-31G(d) and CEP-31G basis sets for second deprotonated species of thiacalix[4]arene and metal ion, respectively. ${ }^{c}$ The values in parentheses are corrected for BSSE.

both adjacent phenol oxygens, was also considered in this study, but no stable structures were obtained from the calculations.

The energetic analysis of all the binding modes carried out in this study is summarized in Table 4 . Binding energies, $\Delta E_{\text {bind, }}$, are defined as the total energy of the complex minus the sum of the total energies of the metal ion and the most stable free second deprotonated species, that is, the opposite phenolates structure. The $\Delta E_{\text {bind }}$ values for all the binding modes of $\mathrm{Zn}^{2+}$ were corrected for BSSE. These corrected $\Delta E_{\text {bind }}$ values are also presented in Table 4 . The BSSE can slightly reduce the $\Delta E_{\text {bind }}$ results of each binding mode by ca. $8 \mathrm{kcal} \mathrm{mol}^{-1}$ for B3LYP and $7 \mathrm{kcal} \mathrm{mol}^{-1}$ for PBE1PBE calculations. All the results support a stronger complex with $\mathrm{Cu}^{2+}$ than with $\mathrm{Zn}^{2+}$ for all types of binding modes, agreeing well with the previous experimental results which proposed higher complexation ability of $p$-tert-butylthiacalix[4] arene to $\mathrm{Cu}^{2+} .{ }^{\mathrm{a}}, 24$ Binding energies relative to that of the most stable complex, $\Delta E_{\text {rel }}$, are also reported in Table 4. 6A is always the most stable binding mode predicted by both B3LYP and PBE1PBE functionals. They also predict the same stability ordering for all the $\mathrm{Zn}^{2+}$ complexes, but some discrepancies are found for $\mathrm{Cu}^{2+}$. For example, the stability ordering obtained at the B3LYP level establishes that $\mathbf{1 B}<\mathbf{5 B}<\mathbf{1 A}<\mathbf{6 B}$, whereas at the PBE1PBE level, it is $\mathbf{5 B}$ $<6 \mathrm{~B}<1 \mathrm{~B}<1 \mathrm{~A}$. However, the energy difference between these binding modes is less than $3.0 \mathrm{kcal} \mathrm{mol}^{-1}$, suggesting that alternation among them can easily occur. The effect of BSSE does not modify the binding energy ordering of $\mathrm{Zn}^{2+}$ complexes at B3LYP, whereas some permutation between $\mathbf{1 A}$ and $\mathbf{1 B}$ was found at the BSSE-corrected PBE1PBE values. Once again, the small $\Delta E_{\text {bind }}$ between those binding modes (less than $1.0 \mathrm{kcal}$ $\mathrm{mol}^{-1}$ ) may suggest the possibility of interconversion between each other.

Some relevant geometrical parameters of all the binding modes are gathered in Tables 5-7. The $\mathrm{M}-\mathrm{O}^{-}$bond lengths are always shorter than the $\mathrm{M}-\mathrm{O}$ bond lengths, which reveals the importance of the electrostatic component in the interaction with the metal ion. The most stable complexes for both metals adopts a distorted square planar coordination to the central metal 


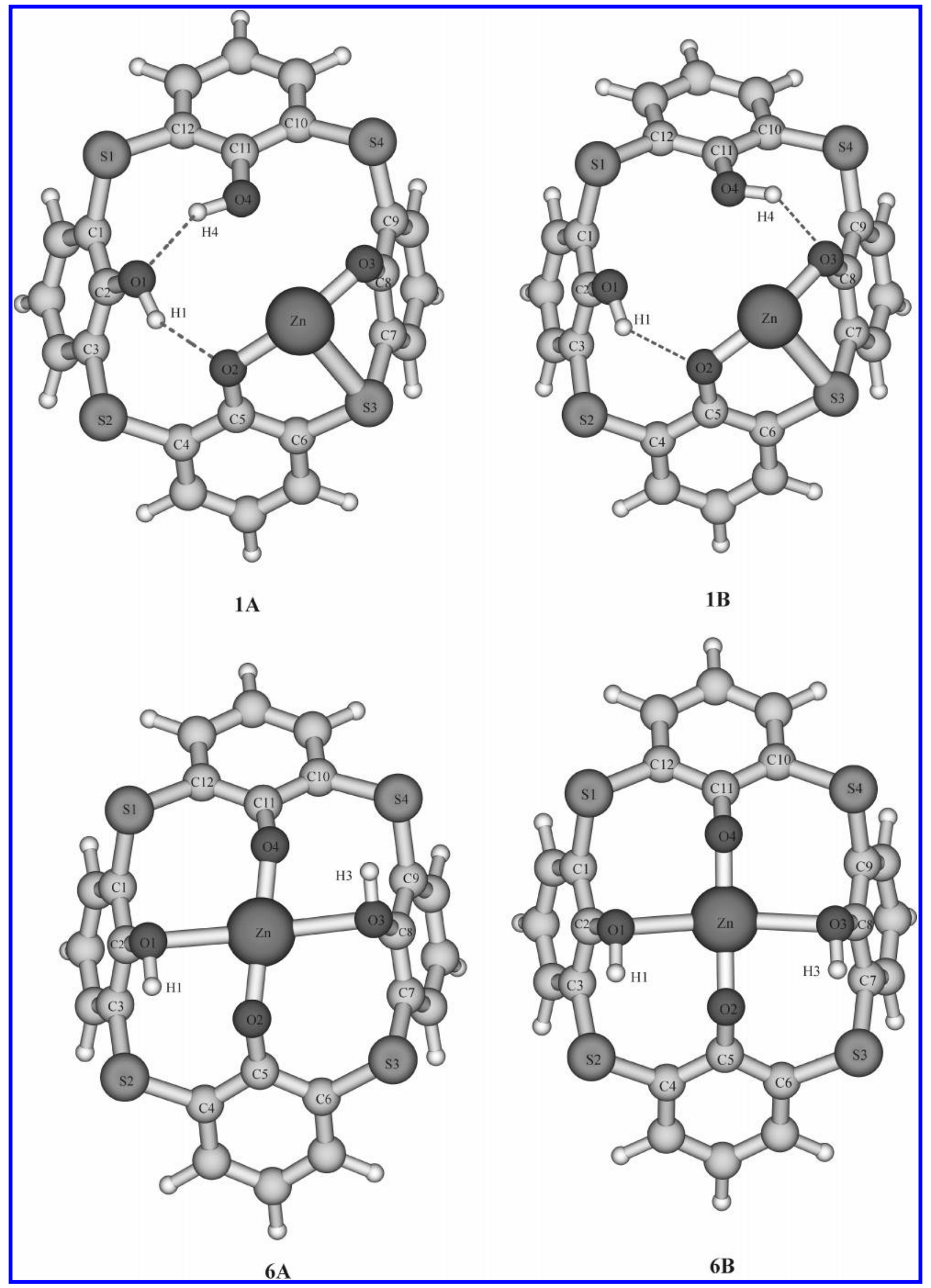

Figure 3. Binding modes for the coordination of $\mathrm{Zn}^{2+}$ by thiacalix[4]arene obtained at the B3LYP level, using the 6-31G(d) and CEP-31G basis sets for free-second deprotonated ligand and $\mathrm{Zn}^{2+}$, respectively. 


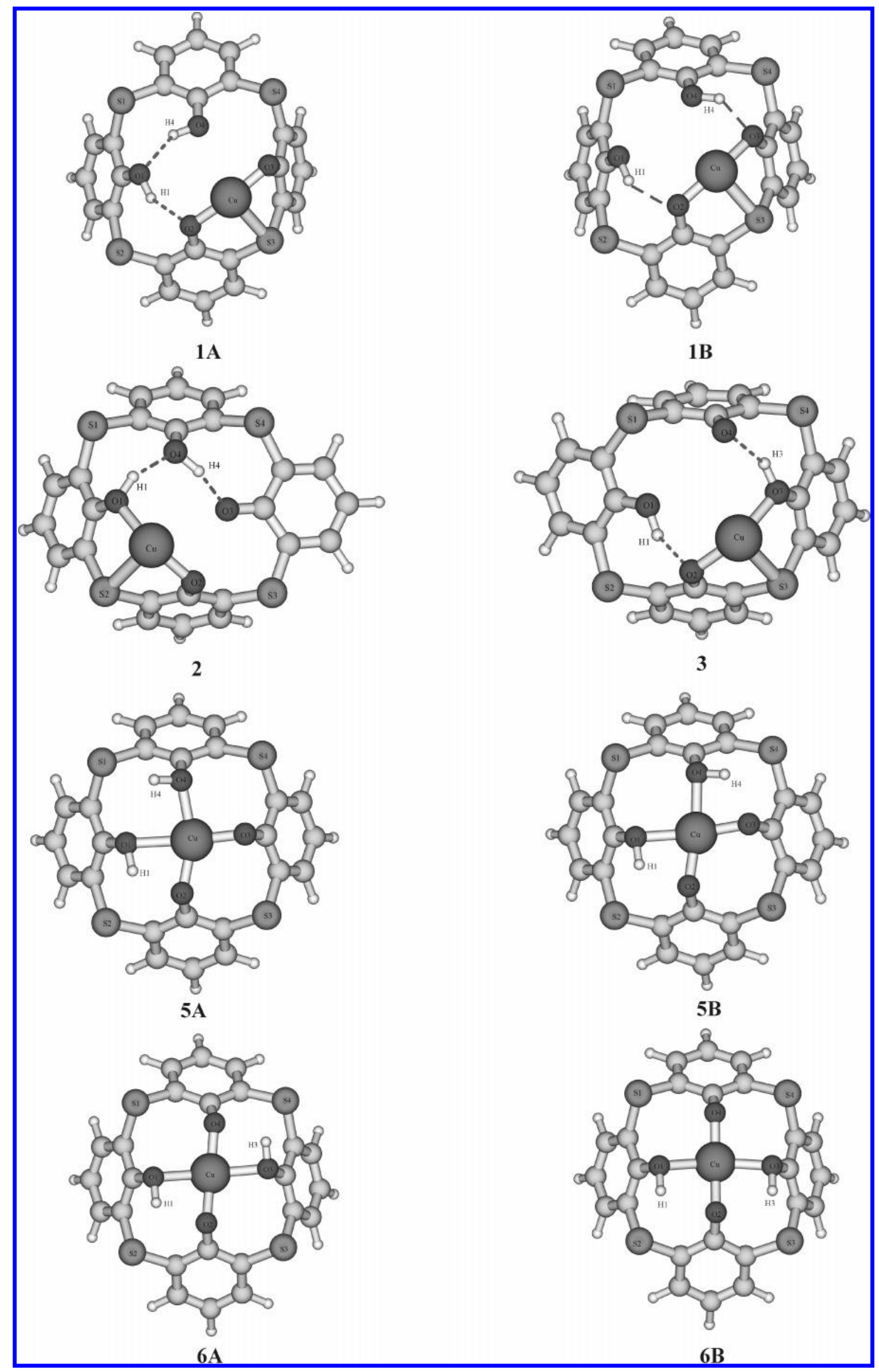

Figure 4. Binding modes for the coordination of $\mathrm{Cu}^{2+}$ by thiacalix[4]arene obtained at B3LYP level, using the 6-31G(d) and CEP-31G basis sets for free-second deprotonated ligand and $\mathrm{Cu}^{2+}$, respectively. 
TABLE 5: Structural Parameters for the Complexes of Thiacalix[4]arene with $\mathrm{Zn}^{2+a}$ (Atom Numbering Corresponds to Figure 3)

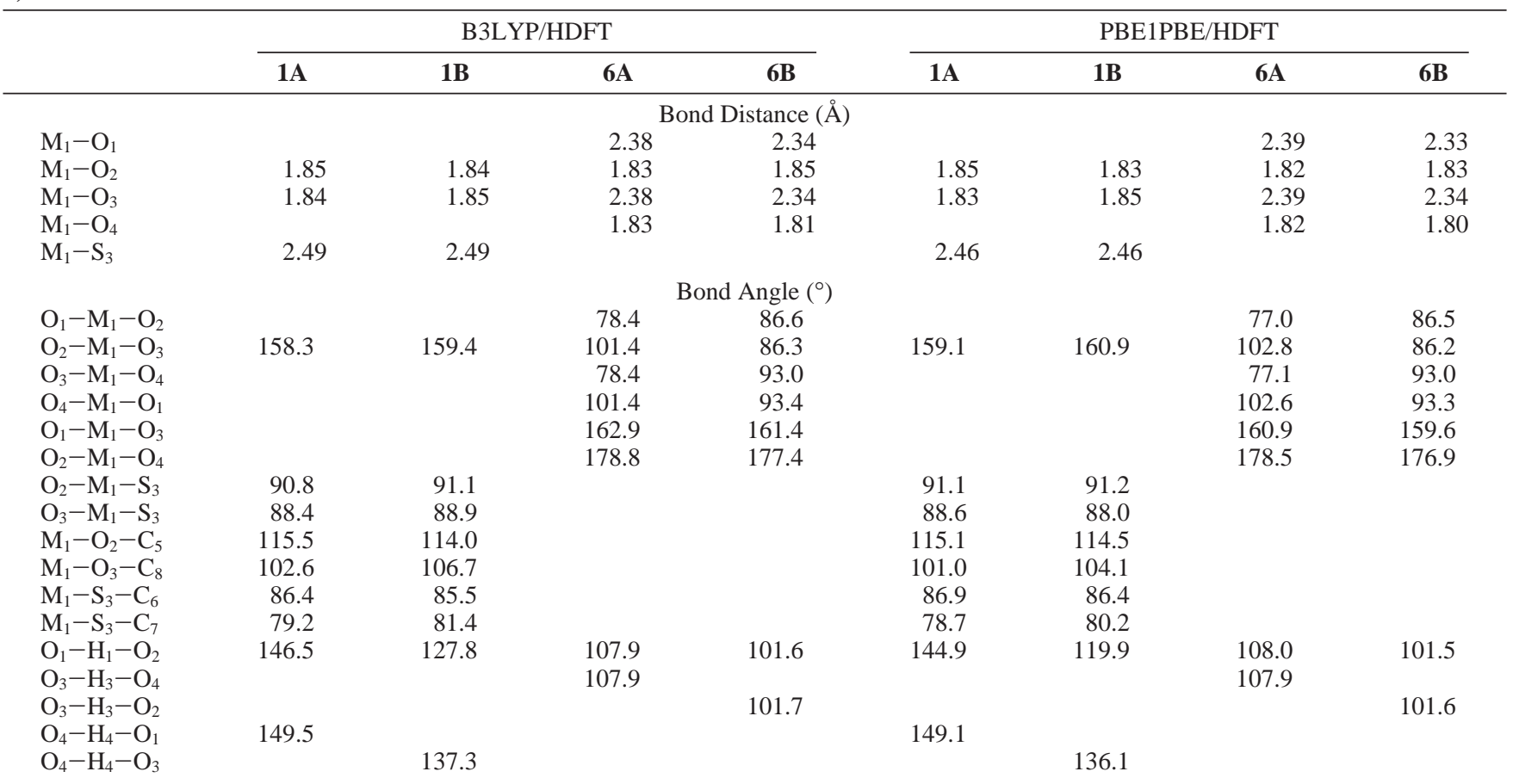

${ }^{a}$ All binding modes of $\mathrm{Zn}^{2+}$ were optimized at B3LYP and PBE1PBE using the 6-31G(d) and CEP-31G basis sets for second deprotonated species of thiacalix[4]arene and metal ion, respectively.

TABLE 6: Structural Parameters for the Complexes of Thiacalix[4]arene with $\mathrm{Cu}^{2+} \mathrm{at} \mathrm{B3LYP}^{a}$ (Atom Numbering Corresponds to Figure 4)

\begin{tabular}{|c|c|c|c|c|c|c|c|c|}
\hline & $\mathbf{1 A}$ & 1B & 2 & 3 & $\mathbf{5 A}$ & $5 B$ & $6 A$ & $6 B$ \\
\hline $\mathrm{M}_{1}-\mathrm{O}_{1}$ & & & 2.00 & & 2.29 & 2.15 & 2.14 & 2.15 \\
\hline $\mathrm{M}_{1}-\mathrm{O}_{2}$ & 1.85 & 1.83 & 1.90 & 1.92 & 1.90 & 1.90 & 1.88 & 1.90 \\
\hline $\mathrm{M}_{1}-\mathrm{O}_{3}$ & 1.82 & 1.85 & & 2.01 & 1.86 & 1.90 & 2.14 & 2.15 \\
\hline $\mathrm{M}_{1}-\mathrm{O}_{4}$ & & & & & 2.13 & 2.13 & 1.88 & 1.84 \\
\hline $\mathrm{M}_{1}-\mathrm{S}_{2}$ & & & 2.55 & & & & & \\
\hline $\mathrm{M}_{1}-\mathrm{S}_{3}$ & 2.38 & 2.37 & & 2.49 & & & & \\
\hline $\mathrm{O}_{1}-\mathrm{M}_{1}-\mathrm{O}_{2}$ & & & 147.3 & & 76.5 & 78.0 & 80.4 & 85.5 \\
\hline $\mathrm{O}_{2}-\mathrm{M}_{1}-\mathrm{O}_{3}$ & 166.1 & 167.4 & & 146.7 & 106.7 & 107.4 & 99.2 & 85.4 \\
\hline $\mathrm{O}_{3}-\mathrm{M}_{1}-\mathrm{O}_{4}$ & & & & & 93.9 & 79.3 & 80.4 & 93.9 \\
\hline $\mathrm{O}_{4}-\mathrm{M}_{1}-\mathrm{O}_{1}$ & & & & & 82.5 & 95.0 & 99.2 & 93.9 \\
\hline $\mathrm{O}_{1}-\mathrm{M}_{1}-\mathrm{O}_{3}$ & & & & & 173.6 & 173.1 & 170.1 & 166.1 \\
\hline $\mathrm{O}_{2}-\mathrm{M}_{1}-\mathrm{O}_{4}$ & & & & & 158.8 & 172.5 & 174.5 & 173.4 \\
\hline $\mathrm{O}_{1}-\mathrm{M}_{1}-\mathrm{S}_{2}$ & & & 84.9 & & & & & \\
\hline $\mathrm{O}_{2}-\mathrm{M}_{1}-\mathrm{S}_{2}$ & & & 87.7 & & & & & \\
\hline $\mathrm{O}_{2}-\mathrm{M}_{1}-\mathrm{S}_{3}$ & 91.3 & 90.7 & & 88.2 & & & & \\
\hline $\mathrm{O}_{3}-\mathrm{M}_{1}-\mathrm{S}_{3}$ & 87.6 & 88.3 & & 86.3 & & & & \\
\hline $\mathrm{M}_{1}-\mathrm{O}_{1}-\mathrm{C}_{2}$ & & & 117.6 & & & & & \\
\hline $\mathrm{M}_{1}-\mathrm{O}_{2}-\mathrm{C}_{5}$ & 113.9 & 113.1 & 106.9 & 111.1 & & & & \\
\hline $\mathrm{M}_{1}-\mathrm{O}_{3}-\mathrm{C}_{8}$ & 102.2 & 106.3 & & 115.7 & & & & \\
\hline $\mathrm{M}_{1}-\mathrm{S}_{2}-\mathrm{C}_{3}$ & & & 89.9 & & & & & \\
\hline $\mathrm{M}_{1}-\mathrm{S}_{2}-\mathrm{C}_{4}$ & & & 81.8 & & & & & \\
\hline $\mathrm{M}_{1}-\mathrm{S}_{3}-\mathrm{C}_{6}$ & 87.8 & 87.4 & & 85.0 & & & & \\
\hline $\mathrm{M}_{1}-\mathrm{S}_{3}-\mathrm{C}_{7}$ & 81.2 & 83.6 & & 89.3 & & & & \\
\hline $\mathrm{O}_{1}-\mathrm{H}_{1}-\mathrm{O}_{2}$ & 149.4 & 132.2 & & 155.5 & 124.6 & 119.6 & 113.5 & 107.9 \\
\hline $\mathrm{O}_{1}-\mathrm{H}_{1}-\mathrm{O}_{4}$ & & & 153.9 & & & & & \\
\hline $\mathrm{O}_{3}-\mathrm{H}_{3}-\mathrm{O}_{4}$ & & & & 153.8 & & & 113.5 & \\
\hline $\mathrm{O}_{3}-\mathrm{H}_{3}-\mathrm{O}_{2}$ & & & & & & & & 107.9 \\
\hline $\mathrm{O}_{4}-\mathrm{H}_{4}-\mathrm{O}_{1}$ & 149.4 & & & & 108.4 & & & \\
\hline $\mathrm{O}_{4}-\mathrm{H}_{4}-\mathrm{O}_{3}$ & & 138.4 & 160.9 & & & 117.5 & & \\
\hline
\end{tabular}

${ }^{a}$ All binding modes of $\mathrm{Cu}^{2+}$ were optimized at B3LYP using the 6-31G(d) and CEP-31G basis sets for second deprotonated species of thiacalix[4]arene and metal ion, respectively.

ion in 6A, as shown in Figures 3 and 4. The $\mathrm{O}-\mathrm{M}-\mathrm{O}$ bond angles of the $\mathrm{Cu}^{2+}$ complexes are closer to the standard square planar structures $\left(90.0\right.$ and $\left.180^{\circ}\right)$ than those of $\mathrm{Zn}^{2+}$ complexes. This is in a good agreement with the known preference of $\mathrm{Cu}^{2+}$ to form four-coordinated complexes. On the other hand, the $\mathrm{Cu}^{2+}$ complex in $\mathbf{6}$ prefers a slightly distorted square planar coordination when compared with $\mathbf{5}$. However, the formation of $\mathrm{O}-\mathrm{H} \cdots \mathrm{S}$ hydrogen bond seems to be more important than $\mathrm{O}-\mathrm{H} \cdots \mathrm{O}$ hydrogen bond in the stabilization of both $\mathbf{5}$ and $\mathbf{6}$. This is corroborated by the range of the $\mathrm{O}-\mathrm{H}-\mathrm{S}$ angles, 125.0-127.0 and $123.0-127.5^{\circ}$ for the $\mathrm{Zn}^{2+}$ and $\mathrm{Cu}^{2+}$ complexes, respectively, which are larger than the $\mathrm{O}-\mathrm{H}-\mathrm{O}$ angles, 
TABLE 7: Structural Parameters for the Complexes of Thiacalix[4]arene with $\mathrm{Cu}^{2+}$ at PBE1PBE ${ }^{a}$ (Atom Numbering Corresponds to Figure 4)

\begin{tabular}{|c|c|c|c|c|c|c|c|c|}
\hline & $1 \mathrm{~A}$ & 1B & 2 & 3 & $5 \mathrm{~A}$ & 5B & 6A & $6 B$ \\
\hline $\mathrm{M}_{1}-\mathrm{O}_{1}$ & & & 2.00 & & 2.24 & 2.11 & 2.11 & 2.11 \\
\hline $\mathrm{M}_{1}-\mathrm{O}_{2}$ & 1.84 & 1.82 & 1.90 & 1.93 & 1.88 & 1.89 & 1.87 & 1.89 \\
\hline $\mathrm{M}_{1}-\mathrm{O}_{3}$ & 1.82 & 1.85 & & 2.02 & 1.84 & 1.89 & 2.11 & 2.11 \\
\hline $\mathrm{M}_{1}-\mathrm{O}_{4}$ & & & & & 2.11 & 2.11 & 1.87 & 1.83 \\
\hline $\mathrm{M}_{1}-\mathrm{S}_{2}$ & & & 2.47 & & & & & \\
\hline $\mathrm{M}_{1}-\mathrm{S}_{3}$ & 2.34 & 2.34 & & 2.41 & & & & \\
\hline $\mathrm{O}_{1}-\mathrm{M}_{1}-\mathrm{O}_{2}$ & & & 145.1 & & 76.7 & 78.1 & 80.5 & 85.2 \\
\hline $\mathrm{O}_{2}-\mathrm{M}_{1}-\mathrm{O}_{3}$ & 167.1 & 167.9 & & 142.1 & 106.8 & 107.8 & 99.0 & 85.2 \\
\hline $\mathrm{O}_{3}-\mathrm{M}_{1}-\mathrm{O}_{4}$ & & & & & 93.2 & 78.8 & 80.5 & 94.1 \\
\hline $\mathrm{O}_{4}-\mathrm{M}_{1}-\mathrm{O}_{1}$ & & & & & 82.7 & 95.1 & 99.0 & 94.1 \\
\hline $\mathrm{O}_{1}-\mathrm{M}_{1}-\mathrm{O}_{3}$ & & & & & 173.1 & 172.8 & 169.7 & 165.6 \\
\hline $\mathrm{O}_{2}-\mathrm{M}_{1}-\mathrm{O}_{4}$ & & & & & 159.0 & 172.4 & 174.0 & 173.1 \\
\hline $\mathrm{O}_{1}-\mathrm{M}_{1}-\mathrm{S}_{2}$ & & & 85.8 & & & & & \\
\hline $\mathrm{O}_{2}-\mathrm{M}_{1}-\mathrm{S}_{2}$ & & & 88.8 & & & & & \\
\hline $\mathrm{O}_{2}-\mathrm{M}_{1}-\mathrm{S}_{3}$ & 91.6 & 91.4 & & 89.7 & & & & \\
\hline $\mathrm{O}_{3}-\mathrm{M}_{1}-\mathrm{S}_{3}$ & 87.9 & 87.9 & & 87.2 & & & & \\
\hline $\mathrm{M}_{1}-\mathrm{O}_{1}-\mathrm{C}_{2}$ & & & 117.3 & & & & & \\
\hline $\mathrm{M}_{1}-\mathrm{O}_{2}-\mathrm{C}_{5}$ & 113.7 & 113.6 & 105.4 & 110.0 & & & & \\
\hline $\mathrm{M}_{1}-\mathrm{O}_{3}-\mathrm{C}_{8}$ & 100.9 & 104.0 & & 115.5 & & & & \\
\hline $\mathrm{M}_{1}-\mathrm{S}_{2}-\mathrm{C}_{3}$ & & & 91.2 & & & & & \\
\hline $\mathrm{M}_{1}-\mathrm{S}_{2}-\mathrm{C}_{4}$ & & & 82.2 & & & & & \\
\hline $\mathrm{M}_{1}-\mathrm{S}_{3}-\mathrm{C}_{6}$ & 88.4 & 88.3 & & 86.1 & & & & \\
\hline $\mathrm{M}_{1}-\mathrm{S}_{3}-\mathrm{C}_{7}$ & 80.8 & 82.6 & & 91.1 & & & & \\
\hline $\mathrm{O}_{1}-\mathrm{H}_{1}-\mathrm{O}_{2}$ & 147.7 & 124.9 & & 155.9 & 123.8 & 119.0 & 113.0 & 107.7 \\
\hline $\mathrm{O}_{1}-\mathrm{H}_{1}-\mathrm{O}_{4}$ & & & 154.6 & & & & & \\
\hline $\mathrm{O}_{3}-\mathrm{H}_{3}-\mathrm{O}_{4}$ & & & & 153.7 & & & 113.0 & \\
\hline $\mathrm{O}_{3}-\mathrm{H}_{3}-\mathrm{O}_{2}$ & & & & & & & & 107.7 \\
\hline $\mathrm{O}_{4}-\mathrm{H}_{4}-\mathrm{O}_{1}$ & 148.7 & & & & 107.5 & & & \\
\hline $\mathrm{O}_{4}-\mathrm{H}_{4}-\mathrm{O}_{3}$ & & 136.5 & 160.3 & & & 118.0 & & \\
\hline
\end{tabular}

${ }^{a}$ All binding modes of $\mathrm{Cu}^{2+}$ were optimized at PBE1PBE using the 6-31G(d) and CEP-31G basis sets for second deprotonated species of thiacalix[4]arene and metal ion, respectively.

$101.5-108.0^{\circ}$ for $\mathrm{Zn}^{2+}$ complex and $108.0-119.5^{\circ}$ for $\mathrm{Cu}^{2+}$ complex.

$\mathbf{1}$ is the other interesting binding mode where the metal forms two five-membered chelated rings with the contribution of one bridging sulfur and two adjacent phenolate groups, as proposed by previous NMR and X-ray structural analysis., ${ }^{9,10,12}$ The $\mathrm{O}-\mathrm{M}-\mathrm{O}$ bond angles in this binding mode are larger by about $8^{\circ}$ for the $\mathrm{Cu}^{2+}$ complex than for the $\mathrm{Zn}^{2+}$ complex, whereas the $\mathrm{O}-\mathrm{M}-\mathrm{S}$ bond angles seem to remain unchanged. The two $\mathrm{O}-\mathrm{H} \cdots \mathrm{O}$ hydrogen bonds seem to also play an important role in the stabilization of this binding mode (see Figures 3 and 4).

It is interesting to note that the position of the deprotonated phenols might affect the binding pattern of metal complexes. $\mathbf{1 A}$ is the preferential binding mode in the case of adjacent phenolates, in contrast with the opposite phenolates case, where the $6 \mathbf{A}$ is the most stable binding mode. Our theoretical results suggest that the 4-fold coordination of metal in $\mathbf{6}$ is more stable than the coordination in $\mathbf{1}$. These last theoretical predictions do not agree completely with the previous experimental results, $, 9,10,12$ but the discrepancy may be explained by the small energy difference between both binding modes, which is less than 2.5 $\mathrm{kcal} / \mathrm{mol}$ (see Table 4). It is thus possible that the alternation between both structures can easily occur upon complexation. In addition, the X-ray crystallographic data has indicated a double-cone structure for several metal complexes of $p$-tertbutylthiacalix[4]arene, which revealed that the extracted species may be 2:2 complexes $\left[\mathrm{M}_{2}\left(\mathrm{H}_{2} \mathrm{~L}\right)_{2}\right]$ having a similar doublecone structure. ${ }^{10}$ In that proposed complex, two $\mathrm{H}_{2} \mathrm{~L}^{2-}$ ligands in adjacent deprotonated form are connected to each other via coordination of two metal ions using the $\mathrm{O}^{-}, \mathrm{S}$, and $\mathrm{O}^{-}$donor atoms. The protons on the two phenol oxygens are stabilized by hydrogen bonding to the neighboring phenolate oxygens. Consequently, the 2:2 complex in $\mathbf{1}$ has a higher stability than the $1: 1$ complex in $\mathbf{6}$, which is supported by a previous theoretical study for the $\mathrm{Zn}^{2+}$ and $\mathrm{Cu}^{2+}$ complexes obtained at the AM1 level. ${ }^{24}$ This is rationalized by the increasing binding sites in the coordination of the two metal ions.

3.3. Molecular Electrostatic Potential Surface. To understand the role of the electrostatic interactions in metal complexation, molecular electrostatic potential (MEP) surfaces are presented in Figure 5 for the most stable binding modes. An electron density isosurface was constructed for the stable metal complexes, and then the MEP was mapped onto the calculated electron density isosurface of $0.03 \mathrm{e}^{-3}$ by a texture-mapping technique. ${ }^{25}$ For the surfaces, a spectrum of colors from red to blue was established representing a range of values from -0.176 to $+0.235 \mathrm{au}$, respectively. The MEP surfaces (see Figure 5) show that, obviously, the phenolate oxygen atoms have a more negative potential than the phenol oxygen atoms. However, one of the phenolate oxygen atoms is stabilized by phenol hydrogen atom in 1, which is evident from the less negative potential of that phenolate oxygen when compared with the other one. The formation of a type of bifurcated $\mathrm{O}-\mathrm{H} \cdots \mathrm{S}$ hydrogen bond appeared in $\mathbf{1}$ as we can observe from the increase of the electrostatic potential of sulfur atoms involved in those bonds. The MEP surfaces also show the more favorable $\mathrm{O} \cdots \mathrm{H} \cdots \mathrm{S}$ interaction in $\mathbf{6}$ when compared to the $\mathrm{O}-\mathrm{H} \cdots \mathrm{O}$ hydrogen bond. This is explained by the presence of the central metal ion, which prevents hydrogen bonding toward the oxygens. Those two sulfur-bridging atoms show less negative potential than the other ones. It is interesting to note that the electrostatic potential of $\mathrm{Cu}^{2+}$ is lower than $\mathrm{Zn}^{2+}$ for both binding modes and that they have more positive potential in $\mathbf{1 A}$ than in $\mathbf{6 A}$. The sulfurbridging atom that interacts with the metal ion has more positive potential than the other ones. These points indicate that some electronic charge has been transferred from metal to sulfur, which may indicate an important role in the stabilization of the complexes. The MEP surfaces support the stronger interaction 


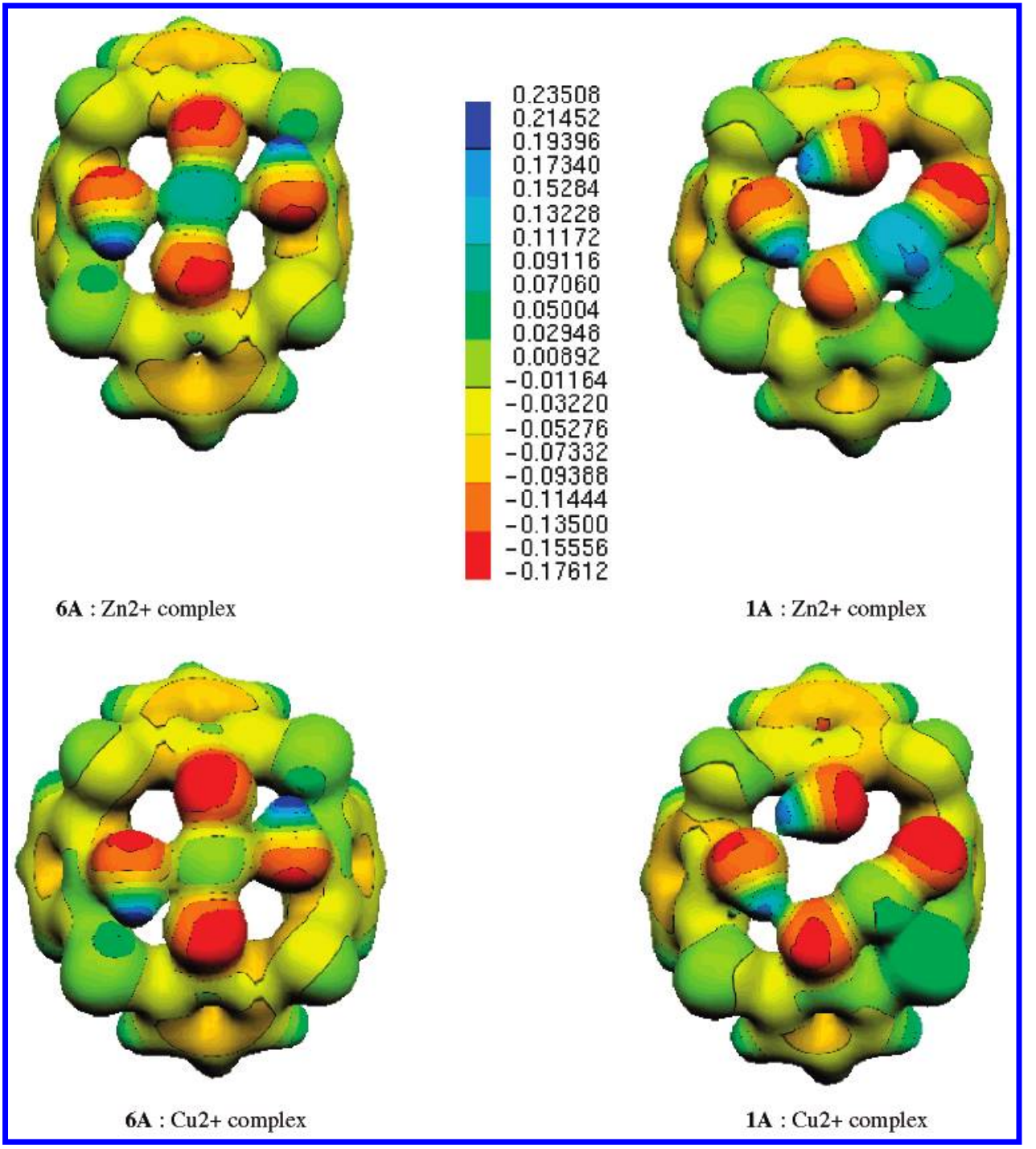

Figure 5. MEP representing a maximum potential, $\phi_{+}=0.235$ au, and a minimum potential, $\phi_{-}=-0.176$ au, mapped onto an electron density isosurfaces of $\rho=0.03 \mathrm{e}^{-3}$ of the most stable binding mode for the coordination of $\mathrm{Zn}^{2+}$ and $\mathrm{Cu}^{2+}$. The most negative and positive electrostatic potential are depicted in red and blue, respectively.

of $\mathrm{Cu}^{2+}$ in both binding modes, which is in a good agreement with the higher complexation ability of $\mathrm{Cu}^{2+}$ obtained from the previous liquid-liquid extraction studies of thiacalix[4]arene. ${ }^{9 a, 24}$ On the other hand, the MEP surfaces help us to visualize the stronger interaction of both metals in the $\mathbf{6}$ when compared with 1.

\section{Conclusion}

The four main conformers of thiacalix[4] arene were studied by two different HDFT methods, namely, B3LYP and PBE1PBE. All the results predict the cone to be the most stable conformer, which agrees well with a previous theoretical work. The intramolecular hydrogen bonds at lower rims seem to be a dominant factor in the stabilization of the different conformers. However, the orientation of the hydrogen bonds toward sulfurbridging atoms plays a crucial role in the stabilizing of the 1,3alt conformer. The structures of neutral and deprotonated species of the cone conformer were also investigated at the same HDFT level. Two different patterns for the second deprotonated species were found. The results showed that the structure with two opposite deprotonated phenol groups is slightly more stable than with two adjacent groups.

The comparative study on the complexation features of thiacalix[4] arene toward the transition-metal ions $\mathrm{Zn}^{2+}$ and $\mathrm{Cu}^{2+}$ were analyzed in detail. Two and five distinct binding modes for $\mathrm{Zn}^{2+}$ and $\mathrm{Cu}^{2+}$, respectively, were obtained and ranked in terms of their relative stability. The position of the deprotonated phenols seems to influence the structural pattern of binding modes. For instance, considering the adjacent phenolates pattern we found a stable 1:1 metal complex where the coordination is made by one bridging sulfur and two phenolate oxygen atoms forming a set of two five-membered rings, which agrees with previous experimental studies. However, the most stable of all the binding modes was predicted to be a 1:1 metal complex in a distorted square planar coordination, using two phenol and two phenolate groups in an opposite pattern. The two structures have an energy gap of ca. $2 \mathrm{kcal} \mathrm{mol}^{-1}$, but the latter one has never been referred to in the literature. The results point to the stronger binding interaction of $\mathrm{Cu}^{2+}$ as compared to $\mathrm{Zn}^{2+}$ in all the binding modes, which is consistent with the available experimental data. The modern PBE1PBE functional yielded almost the same results as B3LYP, though a little discrepancy was found in the stability ordering of binding modes. The PBE1PBE can be an alternative hybrid functional to apply for the study of structure and energetics of the transition metal complexes of thiacalix[4]arene.

The analysis of the MEP surfaces can be a very useful qualitative guideline to understand the different binding interac- 
tions between $\mathrm{Zn}^{2+}$ and $\mathrm{Cu}^{2+}$ complexes. For instance, it shows the importance of the bridging sulfur atoms in the coordination of the metal ions which has never been presented in the "classical" calix[4]arene. This work sheds some light on the characterization of the host-guest properties of metal binding for transition-metal complexes and can help to suggest new approaches for designing cation selective receptors based on thiacalix[4]arenes platforms in future.

Acknowledgment. A. Suwattanamala gratefully acknowledges financial support by the Fundação para a Ciência e a Tecnologia (Lisbon) through Ph.D. Grant SFRH/BD/7077/2001. The authors are grateful to Dr. Dietmar Appelhans (Leibniz Institute of Polymer Research Dresden, Dresden, Germany) and Dr. Karsten Gloe (Institute of Inorganic Chemistry, Dresden, Germany) for their fruitful discussion on this topic.

Supporting Information Available: A table giving structural parameters of each species of the cone conformer of thiacalix[4]arene at both B3LYP and PBE1PBE levels with the 6-31G(d) basis set, a table giving total energies, relative binding energies $\left(\Delta E_{\text {rel }}\right)$ of all the binding modes of $\mathrm{Zn}^{2+}$ and $\mathrm{Cu}^{2+}$ at both B3LYP and PBE1PBE levels, and BSSE and BSSEcorrected relative binding energies $\left(\triangle E_{\text {rel }}: \mathrm{BSSE}\right)$ for $\mathrm{Zn}^{2+}$ complexes, and Cartesian coordinates $(\AA)$ for the B3LYPoptimized structures of the $\mathrm{Zn}^{2+}$ and $\mathrm{Cu}^{2+}$ complexes in all binding modes and of the thiacalix[4]arene conformers and of each species of cone conformer. This material is available free of charge via the Internet at http://pubs.acs.org.

\section{References and Notes}

(1) (a) Kumagai, H.; Hasegawa, M.; Miyanari, S.; Sugawa, Y.; Sato, Y.; Hori, T.; Ueda, S.; Kamiyama, H.; Miyano, S. Tetrahedron Lett. 1997, 38, 3971. (b) Sone, T.; Ohba, Y.; Moriya, K.; Kumada, H.; Ito, K. Tetrahedron Lett. 1997, 38, 10689.

(2) (a) Iki, N.; Miyano, S. J. Incl. Phenom. Macroc. Chem. 2001, 41, 99. (b) Shokova, E. A.; Kovalev, V. V. Russ. J. Org. Chem. 2003, 39, 1. (c) Lhoták, P. Eur. J. Org. Chem. 2004, 8, 1675.

(3) (a) Calixarenes 2001; Asfari, Z., Böhmer, V., Harrowfield, J., Vicens, J., Eds.; Kluwer Academic Publishers: Dordrecht, 2001. (b) Calixarenes in Action; Mandolini, L., Ungaro, R., Eds.; Imperial College Press: London, 2000. (c) Gutsche, C. D. Calixarenes Revisited, Monographs in Supramolecular Chemistry; Stoddart, J. F., Ed.; The Royal Society of Chemistry: Cambridge, 1998; Vol. 6. (d) Calixarenes: A Versatile Class of Macrocyclic Compounds; Vicens, J., Böhmer, V., Eds.; Kluwer Academic Publishers: Dordrecht, 1991.

(4) (a) Kim, T. H.; Lee, J. K.; Bok, J. H.; Kim, J. S.; Kim, H. Electrochim. Acta 2004, 49, 3759. (b) Zlatušková, P.; Stibor, I.; Tkadlecová, M.; Lhoták, P. Tetrahedron 2004, 60, 11383. (c) Appelhans, D.; Stastny, V.; Komber, H.; Voigt, D.; Lhoták, P., Stibor, I. Tetrahedron Lett. 2004, 45, 7145. (d) Iki, N.; Kabuto, C.; Fukushima, T.; Kumagai, H.; Takeya, H.; Miyanari, S.; Miyashi, T.; Miyano, S. Tetrahedron 2000, 56, 1437.

(5) Bernardino, R. J.; Costa Cabral, B. J. THEOCHEM 2001, 549, 253

(6) Suwattanamala, A.; Magalhães, A. L.; Gomes, J. A. N. F. Chem. Phvs. Lett. 2004, 385, 368 .
(7) Suwattanamala, A.; Magalhães, A. L.; Gomes, J. A. N. F. Chem. Phvs. 2005, 310, 109.

(8) Lamrtine, R.; Bavoux, C.; Vocanson, F.; Martin, A.; Senlis, G.; Perrin, M. Tetrahedron Lett. 2001, 42, 1021

(9) (a) Iki, N.; Morohashi, N.; Narumi, F.; Miyano, S. Bull. Chem. Soc. Jpn 1998, 71, 1597. (b) Iki, N.; Kumagai, H.; Morohashi, N.; Ejima, K.; Hasegawa, M.; Miyanari, S.; Miyano, S. Tetrahedron Lett. 1998, 39 , 7559 .

(10) Iki, N.; Morohashi, N.; Yamane, Y.; Miyano, S. Bull. Chem. Soc. Jpn. 2003, 76, 1763.

(11) Ruangpornvisuti, V. THEOCHEM 2004, 683, 103.

(12) Iki, N.; Morohashi, N.; Kabuto, C.; Miyano, S. Chem. Lett. 1999, 219.

(13) (a) Perdew, J. P.; Burke, K.; Ernzerhof, M. Phvs. Rev. Lett. 1996, 77, 3865. (b) Perdew, J. P.; Burke, K.; Ernzerhof, M. Phvs. Rev. Lett. 1997, 78,1396 .

(14) (a) Ernzerhof, M.; Scuseria, G. E. J. Chem. Phvs. 1999, 110, 5029.

(b) Adamo, C.; Barone, V. J. Chem. Phvs. 1999, 110, 6158.

(15) (a) Becke, A. D. J. Chem. Phvs. 1993, 98, 5648. (b) Becke, A. D. Phvs. Rev. A 1988, 38, 3098. (c) Lee, C.; Yang, W.; Parr, R. G. Phys. Rev. $B$ 1988, 37, 785 .

(16) (a) Stevens, W. J.; Basch, H.; Krauss, M. J. Chem. Phvs. 1984, 81, 6026. (b) Stevens, W. J.; Krauss, M.; Basch, H.; Jasien, P. G. Can. J. Chem. 1992, 70, 612. (c) Cundari, T. R.; Stevens, W. J. J. Chem. Phvs. 1993, 98, 5555.

(17) Simon, S.; Duran, M.; Dannenberg, J. J. J. Chem. Phvs. 1996, 105, 11024

(18) Frisch, M. J.; Trucks, G. W.; Schlegel, H. B.; Scuseria, G. E.; Robb, M. A.; Cheeseman, J. R.; Montgomery, J. A., Jr.; Vreven, T.; Kudin, K. N.; Burant, J. C.; Millam, J. M.; Iyengar, S. S.; Tomasi, J.; Barone, V.; Mennucci, B.; Cossi, M.; Scalmani, G.; Rega, N.; Petersson, G. A.; Nakatsuji, H.; Hada, M.; Ehara, M.; Toyota, K.; Fukuda, R.; Hasegawa, J.; Ishida, M.; Nakajima, T.; Honda, Y.; Kitao, O.; Nakai, H.; Klene, M.; Li, X.; Knox, J. E.; Hratchian, H. P.; Cross, J. B.; Adamo, C.; Jaramillo, J.; Gomperts, R.; Stratmann, R. E.; Yazyev, O.; Austin, A. J.; Cammi, R.; Pomelli, C.; Ochterski, J. W.; Ayala, P. Y.; Morokuma, K.; Voth, G. A.; Salvador, P.; Dannenberg, J. J.; Zakrzewski, V. G.; Dapprich, S.; Daniels, A. D.; Strain, M. C.; Farkas, O.; Malick, D. K.; Rabuck, A. D.; Raghavachari, K.; Foresman, J. B.; Ortiz, J. V.; Cui, Q.; Baboul, A. G.; Clifford, S.; Cioslowski, J.; Stefanov, B. B.; Liu, G.; Liashenko, A.; Piskorz, P.; Komaromi, I.; Martin, R. L.; Fox, D. J.; Keith, T.; Al-Laham, M. A.; Peng, C. Y.; Nanayakkara, A.; Challacombe, M.; Gill, P. M. W.; Johnson, B.; Chen, W.; Wong, M. W.; Gonzalez, C.; Pople, J. A. GAUSSIAN 03; Gaussian, Inc.; Pittsburgh, PA, 2003.

(19) Schaftenaar, G.; Noordik, J. H. J. Comput.-Aided Mol. Des. 2000 , 14,123 .

(20) Flükiger, P.; Lüthi, H. P.; Portmann, S.; Weber, J. MOLEKEL 4.3: Molecular Visulaization Software; Swiss Center for Scientific Computing; Manno, Switzerland, 2000. 9080.

(21) Bernardino, R. J.; Costa Cabral, B. J. J. Phvs. Chem. A 1999, 103,

(22) Akdas, H.; Bringel, L.; Graf, E.; Mir-Hosseini, W.; Milin, G.; Pansanel, J.; Cian, A.; Fischer, J. Tetrahedron Lett. 1998, 39, 2311.

(23) Kovalenko, V. I.; Chernova, A. V.; Borisoglebskaya, E. I.; Katsyuba, S. A.; Zverev, V. V.; Shagidullin, R. R.; Antipin, I. S.; Soloveva, S. E.; Stoikov, I. I.; Konovalov, A. I. Russ. Chem. Bull. Int. Ed. 2002, 51, 825 .

(24) Suwattanamala, A.; Appelhans, D.; Wenzel, M.; Gloe, K.; Magalhães, A. L.; Gomes, J. A. N. F. Chem. Phys. In press.

(25) Teschner, M.; Henn, C.; Vollhardt, H.; Reiling, S.; Brickmann, J. J. Mol. Graph. 1994, 12, 98 . 